\title{
First report of Rhizoctonia solani AG 1-IB causing root and stem rot of kale (Brassica oleracea var. acephala) in Turkey
}

\author{
Halil İbrahim Benli ${ }^{1} \cdot$ Muharrem Türkkan ${ }^{1}$ (D) - Göksel Özer ${ }^{2} \cdot$ İsmail Erper ${ }^{3,4}$
}

Received: 22 June 2020 / Accepted: 18 January 2021 / Published online: 25 January 2021

(c) Società Italiana di Patologia Vegetale (S.I.Pa.V.) 2021

Keywords Kale $\cdot$ Rhizoctonia solani $\cdot$ ITS region

Kale (Brassica oleracea L. var. acephala) has been commonly cultivated in the Ordu province, which is located in Turkey's Middle Black Sea Region. In a survey carried out in Çaybaş1 district of the province in 2018, symptoms of damping-off and stem rot were observed in approximately $7 \%$ of the plants in only one of the 10 commercial fields examined. Infected plant tissues were superficially disinfected for $1 \mathrm{~min}$ in $1 \% \mathrm{NaOCl}$ and transferred to Petri dishes containing Potato Dextrose Agar (PDA) amended with streptomycin sulfate. After 2 days of incubation at $25^{\circ} \mathrm{C}$ in the dark, the growing fungal colonies were morphologically similar to Rhizoctonia-like fungi. The young hyphae of Rs-16 isolate from pure culture were $8.90 \mu \mathrm{m}$ (7.5-10.25 $\mu \mathrm{m}$ ) wide with 7.9 nuclei (3-11) per cell. The colony of the three-week PDA culture of the isolate was grayish-orange in colour and produced sclerotia, $0.65 \mathrm{~mm}(0.21-1.10 \mathrm{~mm})$ in diameter, superficially dispersing on the culture. The identification of anastomosis group (AG) of the isolate was performed by sequencing of the internal transcribed spacer (ITS) region. The ITS sequence of the isolate (GenBank accession No. MT568768) was $100 \%$ identical to $R$. solani AG 1-IB sequence (AB122139) deposited in the GenBank. The isolate Rs-16 was deposited in culture collection of the Plant Protection Department, Faculty of Agriculture, Ordu University (Accession No:

Muharrem Türkkan

muharremturkkan@odu.edu.tr;

muharremturkkan@gmail.com

1 Plant Protection Department, Agriculture Faculty, Ordu University, 52200 Ordu, Turkey

2 Plant Protection Department, Agriculture, Abant Izzet Baysal University, 14030 Bolu, Turkey

3 Plant Protection Department, Agriculture Faculty, Ondokuz Mayis University, Atakum, 55139 Samsun, Turkey

4 Plant Protection Department, Agriculture Faculty, Kyrgyz-Turkish Manas University, 720044 Bishkek, Kyrgyzstan
ODU-ZRT 2020-0078). For pathogenicity assay, the roots of three-week-old seedlings of local kale cv. Karadeniz (six replicates) were inoculated with $R$. solani AG 1-IB-infested wheat kernels (Türkkan et al. 2020). Seven days after inoculation, the seedlings infected with $R$. solani AG 1-IB showed symptoms of root and stem rot, while no symptoms were observed in noninfected control seedlings. The pathogen was re-isolated to fulfill Koch's postulates. To our knowledge, this is the first report of $R$. solani AG 1-IB causing root and stem rot of kale plants in Turkey (Farr and Rossman 2020).

\section{Compliance with ethical standards}

Conflict of interest The authors declare that they have no conflict of interest.

Research involving human participants and/or animals The authors declare that no human participants and animals were involved in this study.

Informed consent This manuscript is new and not being considered elsewhere. All authors have approved the submission of this manuscript.

\section{Reference}

Farr DF, Rossman AY (2020) Fungal Databases, U.S. National Fungus Collections, ARS, USDA. https://nt.ars-grin.gov/fungaldatabases/. Accessed 20 June 2020

Türkkan M, Kılıçoğlu MÇ, Erper I (2020) Characterization and pathogenicity of Rhizoctonia isolates collected from Brassica oleracea var. acephala in Ordu Turkey. Phytoparasitica 48:273-286

Publisher's Note Springer Nature remains neutral with regard to jurisdictional claims in published maps and institutional affiliations. 